\title{
Impact on Knowledge Gain, Income and Employment through Intervention of Krishi Vigyan Kendra Training Programmes in Nagaland
}

\author{
Imsunaro Jamir and Amod Sharma* \\ Department of Agricultural Economics, Nagaland University SASRD Medziphema Campus, \\ District: Dimapur - 797 106, Nagaland, India \\ *Corresponding author
}

A B S T R A C T

Keywords

KVK, Impact, Training, Income, Employment, Programme

Article Info

Accepted:

18 October 2018

Available Online:

10 November 2018
The present study on access the impact of Krishi Vigyan Kendra for conducting the training programmes in the selected districts of the Nagaland during the year 2012-13 to 2016-17 and also to assess the impact of income as well as employment generated for that purpose it was categorized into two groups viz., adopted and non-adopted villages (80 respondents to each category which make a total of 160 respondents). To achieve the objectives of the present study a multi stage purpose random sampling methods was adopted. The overall annual income in the KVK's adopted villages was increased after taking the different schemes / programme implemented in both the districts and the overall incremental employment generates in mandays per annum on KVK's adopted villages enhanced as compare to the non-adopted KVK's villages, even the impact of KVK's training / programme on their overall knowledge level was enhanced with 22.00 per cent, which was found to be positive and statistically significant at 5 per cent level.

\section{Introduction}

The state also has abundant resources of mineral wealth in the form of vast deposits of Oil, Coal, Peat, Limestone, Iron ores and various other minerals. The potential of this state in terms of the sheer variety of Agro and Horticultural produce including Fiber, Tea, Coffee, Pineapple, Orange etc. is also immense. In spite of this inherent potential, the state has not developed. The current practice of agriculture is largely unsustainable owing to the traditional Jhum (Shifting cultivation) cycle mode of operation. Though some dynamic initiatives (e.g. by various government, Department, NGO's etc.) are in action to mitigate the detrimental effects of Jhum, a lot still needs to be done on various fronts including efforts on checking deforestation, control of wild fire, conservation of biodiversity, proper water harvesting, use of non-conventional energy sources etc. The state also lacks infrastructure development in terms of networking with the rest of the country, lack of proper communication in terms of roads and information technology.

During the last decade, the cropping intensity remained constant at about 110.00 per cent. The cropping season which begins in March and continues up to August is Kharif while the 
Rabi season starts in September and ends in December every year. Rabi crops are mainly confined to vegetables. Rice is the staple food of the peoples; hence paddy is the major crop in the state. Use of technological interventions in terms of improved seeds, fertilizers and better implements has been limited. The mechanization of agriculture has been poor because of the nature of the terrain in the state and the low purchasing power of the farmers. The consumption of fertilizers and pesticide has not been uniform and almost negligible until recently. The state government is trying to turn this into an advantage by accessing markets for organic foods. The state department of agriculture has established a research station at Mokokchung with three other sub-stations in the state to adopt technological innovation for local use (Annon, 2017).

Since KVK has taken up good step in this direction and results are very encouraging since 1988-1989 in Nagaland. Therefore, it is foremost need to evaluate the performance of KVK by this investigation; so to access the impact or benefits gained by the farming community in term of income and employment can be justified. In the region farmers possess very small size of holdings and family labour (male, female \& children) remains underemployed. Seasonal employment is a chronic affair. Hence farmer needs subsidiary occupation, which may lead to generate additional employment and income as well as infrastructure through $\mathrm{KVK}$ training, so that government as well as local inhabitants should give more attention for implementation of KVK programme in the region, as the scheme has been implemented in all eleven district of Nagaland State.

The effectiveness of the KVK was further enhanced by adding the activities related to on-farm testing and Front-Line Demonstration on major agricultural technologies in order to make the training of farmers location specific, need based and resource-oriented. The training programmes were designed to impart the latest knowledge to the farmers through work experience by applying the principles of 'Teaching by Doing' and 'Learning by Doing'. The prime goal of KVK is to impart training as per needs and requirements in agriculture and allied enterprises to all farmers, farm women and farm youths including school drop-outs in the rural area. While designing the courses, the concept of farming system as well as farming situation are taken into account to ensure that the enterprises in which they are trained are commercially and ecologically viable, sustainable and profitable. Such vocational trainings help them to sustain themselves through self-employment and to make them self-reliant economically and thus discourages them to migrate to the urban areas.

KVKs provide training not only in agriculture and allied vocations but also in other incomegenerating activities that may supplement the income of farm families. The methods employed in training could be formal and nonformal or a combination of both, depending upon the needs but emphasis remains to be on work-experience. The programmes of each KVK's cover training, on-farm trials, frontline demonstrations, agricultural extension and livelihood activities to assess the impact of KVK's training in terms of income and employment as well as to compare the impact of KVK's trainings in adopted and nonadopted villages.

\section{Materials and Methods}

The present study is to access the impact of KVK for disseminating the agriculture technology to the farming community in Nagaland state, which is working as per the guideline of Central Government with the help of Ministry of Agriculture, Government of 
India. The sampling design and analytical techniques to be used in the light of objectives laid down for the study have been presented under the following sub-headings.

The develop projects require long period of time to reap the benefits; therefore for economic appraisal of development, it is essential that the scheme has been in operation for quite some time. Since the intensive KVK started in 1988-89, so it is worth -while to study its impact. Since the data of the initial period cannot be compared with the data of recent years, it is more scientific and practical to compare the economy of the beneficiaries / trainees covered in the area of KVK schemes.

The KVK was launched in 1988-89 in all 11 districts viz; Dimapur, Kohima, Kheprie, Longleng, Mokokchung, Mon, Phek, Peren, Tuensang, Wokha and Zunhebuto of Nagaland, out of these districts two district viz; Mokokchung and Zunhebuto districts of Nagaland have been selected because of the fact that it is expected to provide all the relevant information and hence can conveniently be obtained for conducting this study. The project area also has a good network of infrastructure and allied activities related to the scheme such as development agencies, nationalized banks, well-established marketing and communication facilities etc. Keeping all the above facts, both districts of Nagaland are therefore purposively selected to conduct this study.

Two blocks from each district will be selected randomly for the present study as these blocks are well covered by KVK programme.

Altogether eight villages were selected randomly from each district, while four villages from each block were selected and listed which would be obtained from the offices of SDO (Civil), R. D. block headquarter and other related offices.
However, it is proposed to select four villages from each block randomly covered for KVK programme / schemes.

After selection of the villages, a list of beneficiaries and non-beneficiaries of $\mathrm{KVK}$ will be prepared from each of the selected village.

In order to have representative sample from each village a sample of 20 numbers of cases of KVK, out of that 10 from beneficiaries and 10 from non-beneficiaries will be drawn following the purposively random sampling method.

This will result in selection of 160 respondents from 8 villages, out of which 80 will be beneficiaries of KVK schemes and 80 will be non-beneficiaries of KVK schemes.

The study will be based on primary and secondary data. Secondary data will be collected from secondary sources viz; office of the Zonal Project Director Office, Krishi Vigyan Kendra (KVK), KVK Centre at Mokokchung and Zunhebuto districts, various published materials from the Directorate of Agriculture, Directorate of Horticulture, Directorate of Animal Husbandry and Veterinary, Government of Nagaland, etc.; In order to identify the constraints in implementing the KVK programmes, discussion with $\mathrm{KVK}$ functionaries at district level / block level etc. will be conducted. Besides, data on demographic features, land use pattern, livestock population, climate, rainfall, area under irrigation, institutional infrastructure etc; will also be collected from various statistical abstracts of the districts and state which will enlighten the socio-economic and infrastructural scenario of the area under study. The primary data will be collected through pre-tested and pre-structured schedules and questionnaires especially designed for this study. 


\section{Analytical techniques and tools}

Collected data will be scrutinized, tabulated and processed systematically according to the objectives laid down for the study. Tabular and functional analysis will be used to meet the objectives of the study as and where needed, data were analysed by tabular presentation method where frequencies and percentages were used, mean, standard deviations were used to categorise the sample. Impact index was used to find the extent of KVK's training / programme for adopted and non-adopted both groups. Frequency and percentage were used for tabular analysis. Mean and standard deviation were computed to categorize the respondents. Paired ' $t$ ' test was used to know the significance of difference in Impact assessment before and after taking income generating activity. The chi-square analysis was used to find the association between different activities and socio-economic characteristics of respondents. Modified chi-square values were calculated for the data where cell frequencies were less than five.

\section{Results and Discussion}

Table 1 reveals the location / area-wise selected sample respondents on the different activities / trainings conducted by the KVK's in the study areas, as 80 (50.00 per cent) numbers of respondents was selected as adopted and non-adopted of KVK's programme / training and further it was subcategorized in to two groups which make an total of 160 (100.00 per cent), out of the total population 5,709 (100.00 per cent). Out of that from the Mokokchung district under Kubolong block, the total population was 1,826 (31.98 per cent) and Onganpangkong South block was 2,539 (44.47 per cent), whereas from Zunheboto district under Akuluto block, the total population was 962 (16.68 per cent) and from Suruhoto block, the total population was 382 (6.69 per cent), respectively. For keeping in mind the biasness among the adopter and non-adopter the equal importance / wait age were given by doing the selection of 20 number each of sample respondents as adopted and non-adopter from each block of KVK's programme / trainings, while 40 (25.00 per cent) from each selected blocks and 80 (50.00 per cent) from each district, respectively, which make an total of 160 (100.00 per cent) of selected sample size.

Table 2 reveals the annual income level of selected respondents in Rupees per household per annum generated through the different activities / trainings conducted by the KVK's in the study areas, as 80 (50.00 per cent) numbers each of respondents was selected as adopted and non-adopted of KVK's programme / training in to two sub-categories, out of the total 160 (100.00 per cent) respondents selected, for the present study it was categorized into five (5) sub-categories viz; Below Poverty Line (BPL), very low, low, marginal and medium based on the income per household earned in a year. The maximum numbers of respondent was found on marginal group 36 (22.50 per cent) on KVK's adopter, while it was 23 (14.38 per cent) on non-adopter, the medium category also indicate reverse trends on adopter which shows an positive results due to divert towards the more income category as 27 (16.87 per cent) on adopter and it was 18 (11.25 per cent), respectively, which shows an positive impact of KVK's programme / / training /scheme on adopter as compare to the nonadopter.

Table further reveals that the fore-most subcategory was Below Poverty Line (BPL), indicates an positive impact on the adopter group due to found as zero (nil), while on nonadopter it was 2 (1.25 per cent), as per the category the second group as very low group also shows an positive impact on the adopter 4 
(2.50 per cent) only as compare to non-adopter it was 16 (10.00 per cent), while on the third category as low further indicates an positive response on adopter 13 (8.12 per cent) as compare to non-adopter 21 (13.12 per cent), respectively.

Table.1 Location / area wise selected sample respondent

\begin{tabular}{|c|l|c|c|c|c|}
\hline S. N. & \multicolumn{1}{|c|}{ Response } & Total households & Adopted & Non-adopted & Overall \\
\hline A. & Mokokchung district: & & & & \\
\hline 1. & Kubolong & $1826(31.98)$ & $20(12.50)$ & $20(12.50)$ & $40(25.00)$ \\
\hline 2. & Ongpangkong South & $2539(44.47)$ & $20(12.50)$ & $20(12.50)$ & $40(25.00)$ \\
\hline B. & Zunheboto district: & \multicolumn{3}{|l}{} & \\
\hline 3. & Akuluto & $962(16.68)$ & $20(12.50)$ & $20(12.50)$ & $40(25.00)$ \\
\hline 4. & Suruhoto & $382(6.69)$ & $20(12.50)$ & $20(12.50)$ & $40(25.00)$ \\
\hline & $\quad$ Total & $5709(100.00)$ & $80(50.00)$ & $80(50.00)$ & $160(100.00)$ \\
\hline
\end{tabular}

(Parenthesis indicates percentage to the total)

Table.2 Annual income level of selected respondent (Rs / household / year)

\begin{tabular}{|r|l|c|c|c|}
\hline SN & \multicolumn{1}{|c|}{ Category } & Adopted & Non-Adopted & Overall \\
\hline $\mathbf{1 .}$ & Below Poverty Line (Rs 24,000/-) & $0(0.00)$ & $2(1.25)$ & $2(1.25)$ \\
\hline 2. & Very low (Rs 24,001/- to Rs 50,000/-) & $4(2.50)$ & $16(10.00)$ & $20(12.50)$ \\
\hline 3. & Low (Rs 50,001/- to Rs 1,00,000/-) & $13(8.12)$ & $21(13.12)$ & $34(21.25)$ \\
\hline 4. & Marginal (Rs 1,00,001/- to Rs 1,50,000/-) & $36(22.50)$ & $23(14.38)$ & $59(36.88)$ \\
\hline $\mathbf{5 .}$ & Medium (Rs 1,50,001/- \& above) & $27(16.87)$ & $18(11.25)$ & $45(28.12)$ \\
\hline \multicolumn{2}{|c|}{ Total } & $80(50.00)$ & $80(50.00)$ & $160(100.00)$ \\
\hline
\end{tabular}

(Parenthesis indicates percentage to the total)

Table.3 Employment level of selected respondent (Manday / household / year)

\begin{tabular}{|c|l|c|c|c|}
\hline SI. No. & \multicolumn{1}{|c|}{ Category } & Adopted & Non-Adopted & Overall \\
\hline $\mathbf{1 .}$ & Very low (up to 50 MD) & $0(0.00)$ & $1(0.62)$ & $1(0.62)$ \\
\hline $\mathbf{2 .}$ & Low (51 to 100 MD) & $3(1.88)$ & $2(1.25)$ & $5(3.75)$ \\
\hline $\mathbf{3 .}$ & Average (101 to $150 \mathrm{MD})$ & $5(3.12)$ & $12(7.50)$ & $17(10.63)$ \\
\hline $\mathbf{4 .}$ & Marginal (151 to 200 MD) & $15(9.37)$ & $30(18.75)$ & $45(28.13)$ \\
\hline $\mathbf{5 .}$ & Medium (201 to 250 MD) & $32(20.00)$ & $21(13.12)$ & $53(33.12)$ \\
\hline $\mathbf{6 .}$ & High (251 to 300 MD) & $25(15.62)$ & $14(8.75)$ & $39(24.38)$ \\
\hline & Total & $80(50.00)$ & $80(50.00)$ & $160(100.00)$ \\
\hline
\end{tabular}

(Parenthesis indicates percentage to the total)

Table.4 Overall gain in knowledge level (in percentage)

\begin{tabular}{|c|l|c|c|c|c|c|}
\hline S. No. & \multicolumn{1}{|c|}{ Status } & Total & No's & Score & $\%$ & Gain \% \\
\hline 1. & Pre Knowledge & $\mathbf{8 0}$ & $\mathbf{1 8}$ & $\mathbf{1 4 4 0}$ & $\mathbf{0 . 6 0}$ & $\mathbf{0 . 2 2}$ \\
\hline 2. & Post Knowledge & $\mathbf{8 0}$ & $\mathbf{2 2}$ & $\mathbf{1 7 6 0}$ & $\mathbf{0 . 7 3}$ & - \\
\hline & Total & $\mathbf{8 0}$ & $\mathbf{3 0}$ & $\mathbf{2 4 0 0}$ & - & - \\
\hline
\end{tabular}

(* Statistically significant at 5 per cent level) 
Table 3 reveals the employment level of selected respondents in mandays per household per annum generated through the different activities / trainings conducted by the KVK's in the study areas, as 80 (50.00 per cent) numbers each of respondents was selected as adopted and non-adopted of KVK's programme / training in to two subcategories, out of the total 160 (100.00 per cent) respondents selected, for the present study it was categorized into six (6) subcategories viz; very low, low, average, marginal, medium and high based on the employment generated per household in a year. The maximum numbers of respondent was found on medium group 32 (20.00 per cent) on KVK's adopter, while it was 21 (13.12 per cent) on non-adopter, the sixth category as high also indicate reverse trends on adopter which shows an positive results due to diversion towards the more employment category as 25 (15.62 per cent) on adopter and it was 14 (8.75 per cent), respectively, which shows an positive impact of KVK's programme / / training /scheme on adopter as compare to the non-adopter.

Table further reveals that the fore-most subcategory is very low, which indicate an negative impact on the adopter group due to found as zero (nil), while on non-adopter it was 1 (0.62 per cent), as per the second as low group, an positive impact was indicating on the adopter 3 (1.88 per cent), as compare to non-adopter it was 2 (1.25 per cent), while on the third category as average, it indicate an negative response on adopter 5 (3.12 per cent) as compare to non-adopter 12 (7.50 per cent), followed by the fourth category as marginal, indicate an negative response on adopter 15 (9.37 per cent) as compare to non-adopter 30 (18.75 per cent), respectively. The negative response on adopter category indicates towards the more mandays generated due to the intervention of KVK's programme / trainings and further which was shifted towards the higher mandays generated category. Table further reveals that the foremost sub-category is very low, which indicate an negative impact on the adopter group due to found as zero (nil), while on non-adopter it was 1 (0.62 per cent), as per the second as low group, an positive impact was indicating on the adopter 3 (1.88 per cent), as compare to non-adopter it was 2 (1.25 per cent), while on the third category as average, it indicate an negative response on adopter 5 (3.12 per cent) as compare to non-adopter 12 (7.50 per cent), followed by the fourth category as marginal, indicate an negative response on adopter 15 (9.37 per cent) as compare to non-adopter 30 (18.75 per cent), respectively. The negative response on adopter category indicates towards the more mandays generated due to the intervention of KVK's programme / trainings and further which was shifted towards the higher mandays generated category.

Table 4 reveals the overall gain in knowledge level (in percentage) data clearly indicate that numbers of farmers / respondents with pre knowledge about the different programme / activities initially they were 18 with an score of 1440, but after the trainings / activities of KVK's the present / post knowledge has increase up to 22 with an score of 1760 , further the percentage has increase from 60.00 to 73.00 per cent, while the gain percentage was 22.00 per cent overall respectively.

The main conclusion of the study was undertaken in two blocks from each Mokokchung and Zunheboto district by following the purposive stratified random sampling technique methods, further the present study was having positive impact on income, due to shifting from below poverty line to medium group. The employment generated indicates an positive impact shifted from very low group to high group, while 22.00 per cent was gain on the knowledge 
level of the adopter as compare to nonadopter; after the intervention of the KVK's through the conduct their training / programme in the selected study area.

\section{References}

Ahmad, Nafees; Singh, S. P. and Parihar, P. 2012. Farmer's Assessment of KVK training programme. Economic Affairs. 57(2): 165-168.

Ali, Lyaqet. 2001. A study on the changes in cropping pattern income and employment status among beneficiaries of National Watershed Development Project of Panagar block Jabalpur district (MP). M. Sc. (Ag.) Thesis, JNKVV, Jabalpur: 1-106.

Analogous. 2017. Statistical Hand of Nagaland Published by Directorate of Economics and Statistics (various issues), Kohima, Nagaland.

Biswas, S.; Sarkar, A. and Goswami, A. 2008. Impact of KVK training on advance dairy farming practices (ADFPS) in changing knowledge and attitude of Prani-Bandhu. Journal of Dairying, Foods and Home Science 27(1): 43-46.

Chauhan, Lal. Banwari; Chauhan, J. P. S. and Das, B. C. 2005. Impact of KVK training on improved dairy farming practices in changing knowledge and attitude. Journal of Interacademicia. 9(4): 597-599.

Chinchmalatpure, U. R.; Umale, P. B. and Bhople, P. P. 2009. Evaluation of training programmes organized by Maharashtra State Department of Agriculture. Green Farming. 2(11): 793-796.

Dubey, A. K.; Srivastva, J.P.; Singh, R. P. and Sharma, V. K. 2008. Impact of KVK training programme on socio-economic status and knowledge of trainees in Allahabad district. Indian Research
Journal of Extension Education. 8(2-3): 60-61.

Gaikwad, S. P.; Godase, S. S.; Tambe, B. N. 2011. Knowledge gained by farmer by participating in field days organized by K.V.K. Pune. International Journal of Agricultural Sciences. 7(2): 460-461.

Mazumder, G.; Das, J. K.; Mazumdar, D. and Ghoshal. R. 2012. Assessment of yield in KVK programme: a multivariate approach. Journal of Crop and Weed. 8(2): 102-108.

Meena, B. S. and Bhati, D. S. 2010. Impact of Krishi Vigyan Kendra's trainings on knowledge and adoption of cotton production technologies. Agriculture Update. 5(1-2): 92-95.

Mishra, R. P.; Singh, A. K. and Chaudhary, R. P. 2005. Impact of KVK on farm women development. Farm Science Journal. 14(1): 67-68.

Pandhare, S. P.; Nadre, K. R.; Deshmukh, R. S. and Bhosale, P. B. 2012. Adoption of Krishi Vigyan Kendra (KVK) recommended practices. Agriculture Update. 7(1-2): 85-91.

Parihar, Pushpa.; Khare, Neeta. and Gupta, Kiran. 2010. Role of frontline demonstration in transfer of kitchen garden technology to tribal farmwomen of Chhattisgarh. Journal of Soils and Crops. 20(2): 226-228.

Pathak, Chitra. and Kumar. Manish. 2006. Building KVK's as rural knowledge centres. The fifth international conference of the Asian Federation for Information Technology in Agriculture, J. N. Tata Auditorium. Indian Institute of Science Campus, Bangalore, India. 911 November: 7-67.

Patil, S. S. and Kokate, K. D. 2011. Training needs assessment of subject matter specialists of Krishi Vigyan Kendras. Indian Research Journal of Extension Education. 11(1): 18-22. 
Pongener, Bendangjungla and Sharma, Amod. 2018. Constraints Faced by the Fishery Enterprises: A SWOC Analysis. IJCMAS. 7(5). May: 1595-1603.

Rajan, P. 2014. Impact assessment of Krishi Vigyan Kendra Activity on tribal farmer of Madhya Pradesh. Ph. D. Thesis. JNKVV, Jabalpur.

Rao, Hanumantha. 1994. Report of the Technical Committee on Drought Prone Areas Programme and Desert Development Programme, Ministry of Rural Development, New Delhi.

Rao, N. V.; Ratnakar, R. and Jain, P. K. 2012. Impact of farmer field schools in KVK adopted villages on level of knowledge and extent of adoption of improved practices of paddy (Oryza sativa L.). Journal of Research ANGRAU. 40(1): $35-41$.

Rao, Sunder. D. 1998. Impact of improved dryland agriculture technology in Chevella and Pothalaboguda model watershed development project in Josipe taluk of Medak district in Andhra Pradesh. M. Sc. (Ag.) Thesis, APAU, Hyderabad.

Rudra, B. C. and Mukhopadhyay, P. 2004. Role of training on adoption of improved package of practices for wheat cultivation in Cooch Behar district of West Bengal. Environment and Ecology. 22(4): 856-860.

Salow, Robert. M. 1957. Technological change and the Aggregate production Function: Review of Economic Statistics. 39: 312-320.

Sharma, A. and Sharma, Anamika. 2008. Problems faced by the farmers in adoption of improved maize cultivation practices in hills. TJRAR. 8(2): 22-23.

Sharma, Amod. 2012. Inter-state Disparities in Socio-economic Development in North East Region of India. Journal of Agricultural Science. 4(9). September: 236-243.
Sharma, Amod.; Kichu, Yimkumba. and Chaturvedi, B. K. 2016. Economics and Constraints of Pineapple Cultivation in Dimapur District of Nagaland. TJRAR. 16(1). January: 72-75.

Sharma, Amod.; Kichu, Yimkumba. and Sharma, Pradeep. Kumar. 2018. Sustainable economic analysis and constraints faced by the pineapple growers in Nagaland. Progressive Agriculture. 18(1). February: 27-33.

Sharma, S. S. 1997. A study of profile characteristics and enhancement in employment crop yields and income of beneficiaries in watershed development project area of Jabalpur district, MP. Ph.D. Thesis, JNKVV, Jabalpur.

Sharma, S. S.; Chobey, C. H.; Pyasi, V. K. and Sharma, L. N. 2000. Impact of Watershed Project in generating employment opportunity. Madhya Journal of Extension Education. 3(2-3): 9-13.

Shelke, P. P. and Lakhdive, B. A. 2012. Use of LCD projector for training and its effect on knowledge gain of trainees of Krishi Vigyan Kendra. International Journal of Agriculture: Research and Review. 2(6): 717-723.

Shuya, Keviu and Sharma, Amod. 2014. Impact and constraints faced by the borrowers of cooperative bank finance in Nagaland. Economic Affairs. 59(4). October: 561-567.

Shuya, Keviu and Sharma, Amod. 2018. Problems faced by the Borrowers in Utilization and Acquiring of Cooperative Bank Loans in Nagaland. IJED. 14(2). April-June: 52-56.

Singh, Balwant. 1998. Adoption of improved practices of kinnow (Amadarin hybrid) in Haryana M.Sc. (Ag.) Thesis, Department of Extension Education, CCS HAU, Hisar.

Singh, D. K.; Singh, A. K.; Yadav, V. P.; Singh, R. B.; Baghel, R. S. and Singh, 
Mayank. 2009. Association of socioeconomic status with economic motivation of the farmers. Indian Research Journal of Extension Education. 9(2): 53-56.

Singh, Dan.; Singh, R. P.; Singh, R. L. and Singh, Surat. 2007. Assessment of training programmes of KVK Rampur, its duration and preference time of training programmes. Progressive Research. 2(1-2): 126-128.

Singh, Dan.; Singh, R. P.; Singh, R. L. and Singh, Surat. 2007. Assessment of training programmes of KVK Rampur, its duration and preference time of training programmes. Progressive Research. 2(1-2): 126-128.

Singh, J. B. and Kumar, Rajesh. 2010. Impact of training on adoption of improved practices for Mentha crop. Journal of Interacademicia. 14(1): 81-84.

Singh, Kuldeep; Peshin, Rajinder. and Saini, S. K. 2010. Evaluation of the agricultural vocational training programmes conducted by the Krishi Vigyan Kendras (Farm Science Centres) in Indian Punjab. Journal of Agriculture and Rural Development in the Tropics and Subtropics. 111(2): 65-77.
Singh, S. P.; Hoodda, R. S. and Verma, H. K. 1991. Knowledge gap of citrus growers. Indian Journal of Extension Education. 27 (1-2): 117-120.

Walling, Imti and Sharma, Amod. 2015. Impact of SGRY on beneficiaries and non-beneficiaries in Dimapur district of Nagaland. TJRAR. 15(2). August: 9094.

Walling, Imti; Sharma, Amod; Yadav, Mukesh. Kumar; Rajbhar, Arun, Kumar. and Kalai, Kankabati. 2017. Impact of Agricultural Technology Management Agency on Rural Economy of Nagaland, India. Plant Archiver. 17(2). October: 1511-1516.

Wanjiku, J.; Mairura, F. and Place, F. 2010. Assessment of professional training programmes in international agricultural research institutions: the case of ICRAF. Journal of Agricultural Education and Extension. 16(4): 413431.

Yerpude Seema and Khare NK. 2003. Constraints in participation of tribal women in watershed programme. Indian Journal of Extension Education. 3(2): 87-88.

\section{How to cite this article:}

Imsunaro Jamir and Amod Sharma. 2018. Impact on Knowledge Gain, Income and Employment through Intervention of Krishi Vigyan Kendra Training Programmes in Nagaland. Int.J.Curr.Microbiol.App.Sci. 7(11): 2323-2331. doi: https://doi.org/10.20546/ijcmas.2018.711.262 